\title{
Selection of marker gene to construct a reference library for wetland plants and application of metabarcoding to analyze diet of wintering herbivorous waterbird
}

\author{
Yuzhan Yang ${ }^{1}$, Aibin Zhan ${ }^{2}$, Lei Cao ${ }^{\text {Corresp., }}{ }^{2}$, Fanjuan Meng ${ }^{2}$, Wenbin Xu ${ }^{3}$ \\ ${ }^{1}$ School of Life Sciences, University of Science and Technology of China, Hefei, Anhui, China \\ 2 Research Center for Eco-Environmental Sciences, Chinese Academy of Sciences, Beijing, China \\ 3 Anhui Shengjin Lake National Nature Reserve Administration, Chizhou, Anhui, China \\ Corresponding Author: Lei Cao \\ Email address: caolei@ustc.edu.cn
}

Food availability and diet selection are important factors influencing the abundance and distribution of wild waterbirds. In order to better understand changes in waterbird population, it is essential to figure out what they feed on. However, analyzing diet could be difficult and inefficient using traditional methods, such as microhistologic observation. Here, we addressed this gap of knowledge by investigating diet of greater white-fronted goose Anser albifrons and bean goose Anser fabalis, which are obligate herbivores wintering in China, mostly in Middle and Lower Yangtze River Floodplain. First, we selected suitable and high-resolution marker gene for wetland plants that these geese would consume during the wintering period. Eight candidate genes were included, $r b c \mathrm{~L}, r p o \mathrm{C} 1$, $r p o \mathrm{~B}$, matK, trnH-psbA, trnL (UAA), atpF-atpH, and psbK-psbl. The selection was performed via analysis of representative sequences from NCBI and comparison of amplification efficiency and resolution power of plant samples collected from the wintering area. The $t r n L$ gene was chosen at last with $\mathrm{c} / \mathrm{h}$ primers and a local plant reference library was constructed with this gene. Then, utilizing DNA metabarcoding, we discovered 15 food items in total from feces of these birds. Of the 15 unique dietary sequences, 10 could be identified at specie-level. As for greater white-fronted goose, $73 \%$ of sequences belonged to Poaceae spp., and $26 \%$ belonged to Carex spp. In contrast, almost all sequences of bean goose belonged to Carex spp. (99\%). Using the same samples, microhistology provided consistent food composition with metabarcoding results for greater white-fronted goose, while $13 \%$ of Poaceae was recovered for bean goose. In addition, two other taxa were discovered only through microhistologic analysis. Although most of the identified taxa matched relatively well between the two methods, DNA metabarcoding gave taxonomically more detailed information. Discrepancies were likely due to biased PCR amplification in metabarcoding, low discriminating power of current marker genes for 
monocots, and biases in microhistologic analysis. The diet differences between two geese species might indicate deeper ecological significance beyond the scope of this study. We concluded that DNA metabarcoding provides new perspectives for studies of herbivorous waterbird diets and inter-specific interactions, as well as new possibilities to investigate interactions between herbivores and plants. In addition, microhistologic analysis should be used together with metabarcoding methods to integrate this information. 
1 Selection of marker gene to construct a reference library for wetland plants and

2 application of metabarcoding to analyze diet of wintering herbivorous waterbird

3 Yuzhan Yang 1 , Aibin $\mathrm{Zhan}^{2}$, Lei $\mathrm{Cao}^{2}$, Fanjuan $\mathrm{Meng}^{2}, \mathrm{Wenbin} \mathrm{Xu}^{3}$

$4 \quad{ }^{1}$ School of Life Sciences, University of Science and Technology of China, Hefei, Anhui, China

$5{ }^{2}$ Research Center for Eco-Environmental Sciences, Chinese Academy of Sciences, Beijing,

6 China

$7 \quad{ }^{3}$ Anhui Shengjin Lake National Nature Reserve Administration, Chizhou, Anhui, China

8 Corresponding Author:

$9 \mathrm{Lei} \mathrm{CaO}^{2}$

1018 Shuangqing Road, Haidian District, Beijing, China, 100085

11 Email address: caolei@ustc.edu.cn 


\section{Abstract}

13 Food availability and diet selection are important factors influencing the abundance and

14 distribution of wild waterbirds. In order to better understand changes in waterbird population, it

15 is essential to figure out what they feed on. However, analyzing diet could be difficult and inefficient using traditional methods, such as microhistologic observation. Here, we addressed this gap of knowledge by investigating diet of greater white-fronted goose Anser albifrons and bean goose Anser fabalis, which are obligate herbivores wintering in China, mostly in Middle and Lower Yangtze River Floodplain. First, we selected suitable and high-resolution marker gene for wetland plants that these geese would consume during the wintering period. Eight candidate genes were included, $r b c \mathrm{~L}, r p o \mathrm{C} 1, r p o \mathrm{~B}, \operatorname{mat\mathrm {K}}, \operatorname{trn\mathrm {H}}-p s b \mathrm{~A}, \operatorname{trn\mathrm {L}}(\mathrm{UAA}), \operatorname{atp} \mathrm{F}-a t p \mathrm{H}$, and $p s b \mathrm{~K}-p s b \mathrm{I}$. The selection was performed via analysis of representative sequences from NCBI and comparison of amplification efficiency and resolution power of plant samples collected from the wintering area. The $\operatorname{trn} \mathrm{L}$ gene was chosen at last with $\mathrm{c} / \mathrm{h}$ primers and a local plant reference library was constructed with this gene. Then, utilizing DNA metabarcoding, we discovered 15 food items in total from feces of these birds. Of the 15 unique dietary sequences, 10 could be identified at specie-level. As for greater white-fronted goose, $73 \%$ of sequences belonged to Poaceae spp., and 26\% belonged to Carex spp. In contrast, almost all sequences of bean goose belonged to Carex spp. (99\%). Using the same samples, microhistology provided consistent food composition with metabarcoding results for greater white-fronted goose, while $13 \%$ of Poaceae was recovered for bean goose. In addition, two other taxa were discovered only through microhistologic analysis. Although most of the identified taxa matched relatively well between 
33 the two methods, DNA metabarcoding gave taxonomically more detailed information.

34 Discrepancies were likely due to biased PCR amplification in metabarcoding, low discriminating

35 power of current marker genes for monocots, and biases in microhistologic analysis. The diet

36 differences between two geese species might indicate deeper ecological significance beyond the

37 scope of this study. We concluded that DNA metabarcoding provides new perspectives for

38 studies of herbivorous waterbird diets and inter-specific interactions, as well as new possibilities

39 to investigate interactions between herbivores and plants. In addition, microhistologic analysis

40 should be used together with metabarcoding methods to integrate this information. 
41

42 Wetlands are one of the most important ecosystems in nature, and they harbor a variety of

43

44

\section{Introduction} ecosystem services such as protection against floods, water purification, climate regulation and recreational opportunities (Brander, Flora \& Vermaat, 2006). Waterbirds are typically wetlanddependent animals upon which they could get abundant food and suitable habitats (Ma et al., 2010). Waterbird abundance and distribution could reflect the status of wetland structure and functions, making them important bio-indicators for wetland health (Fox et al., 2011). Among all factors affecting waterbird community dynamics, food availability is frequently considered to play one of the most important roles (Wang et al., 2013). However, recently suitable food resources have tended to decrease or even disappear due to deterioration and loss of natural wetlands (Fox et al., 2011). As a result, waterbirds are forced to discard previous habitats and sometimes even feed in agricultural lands (Zhang et al., 2011). In addition, migratory waterbirds may aid the dispersal of aquatic plants or invertebrates by carrying and transporting them between water bodies at various spatial scales (Reynolds, Miranda \& Cumming, 2015). Consequently, long-time monitoring and systematic studies of waterbird diets are essential to understand population dynamics of waterbirds, as well as to establish effective management programs for them (Wang et al., 2012).

Traditional methods for waterbird diet analysis were direct observation in the field (Swennen \& Yu, 2005) or microhistologic analysis of remnants in feces and/or gut contents (James \& Burney, 1997; Fox et al., 2007). While these approaches have been proved useful in some cases, they are relatively labor-intensive and greatly skill-dependent (Fox et al., 2007; 
62 Samelius \& Alisauskas, 1999; Symondson, 2002). Applications of other methods for analyzing

63

64 gut contents or feces were also restricted due to inherent limitations, as reviewed by Pompanon et al. (Pompanon et al., 2012). Recently, metabarcoding methods, based on high-throughput sequencing, have provided new perspectives for diet analysis and biodiversity assessment (Taberlet et al., 2007; Creer et al., 2010). These methods provide higher taxonomic resolution and higher detectability with enormous sequence output from large-scale environmental samples, such as soil, water and feces (Shokralla, Spall \& Gibson, 2012; Bohmann et al., 2014). Owing to these advantages, metabarcoding has been widely employed in diet analysis of herbivores (Taberlet et al., 2012; Ando et al., 2013; Hibert et al., 2013), carnivores (Deagle, Kirkwood \& Jarman, 2009; Shehzad et al., 2012) and omnivores (De Barba et al., 2014). But pitfalls of metabarcoding should not be ignored when choosing suitable techniques for new studies. For instance, many researches have shown that it is difficult to obtain quantitative data using metabarcoding (Sun et al., 2015). This drawback might result from both technical issues of this method and relevant biological features of samples (Pompanon et al., 2012).

One paramount prerequisite of metabarcoding methods is to select robust genetic markers and corresponding primers (Zhan et al., 2014; Zhan \& MacIsaac, 2015). For diet studies of herbivores, at least eight chloroplast genes and two nuclear genes are used as potential markers for land plants (Hollingsworth, Graham \& Little, 2001). Although mitochondrial cytochrome $c$ oxidase I (COI) is extensively recommended as a standard barcode for animals, its relatively low rate of evolution in botanical genomes precludes it being an optimum for plants (Wolfe, Li \& Sharp, 1987; Fazekas et al., 2008). The internal transcribed spacer (ITS) is excluded due to 
83 divergence discrepancies of individuals and low reproducibility (Álvarez \& Wendel, 2003). A

84 variety of combinations and comparisons have been performed for the eight candidate genes,

85 however, none proved equally powerful for all cases (Fazekas et al., 2008). Consequently, it is

86 more effective to choose barcodes for a circumscribed set of species occurring in a regional

87 community (Kress et al., 2009). Another equally important aspect of metabarcoding applications

88 is the construction of reference libraries which assist taxonomic assignment (Rayé et al., 2011;

$89 \mathrm{Xu}$ et al., 2015). It is difficult to accurately interpret sequence reads without a reliable reference

90 library (Elliott \& Jonathan Davies, 2014).

91 Diet analysis is one of the central issues in waterbird research, both for deciphering

waterfowl population dynamics and interpreting inter- or intra-specific interactions of

cohabitating species (Zhao et al., 2015). For instance, more than $60 \%$ of bean goose Anser

fabalis and almost $40 \%$ of greater white-fronted goose Anser albifrons populations along the

East Asian - Australian Flyway Route winter at the Shengjin Lake National Nature Reserve

(Zhao et al., 2015). Previous studies based on microhistologic observation illustrated that the

dominant composition of their diets was monocotyledons, such as Carex spp. (Zhao et al., 2012),

Poaceae (Zhang et al., 2011), and a relatively small proportion of non-monocots (referred to as

dicotyledons in study of "Zhao, Cao \& Fox, 2013”). However, few food items could be

identified to species-level, mainly owing to variable tissue structures within plants, similar

morphology between relative species, and a high level of degradation after digestion (Zhang et

al., 2011; Zhao et al., 2012; Zhao, Cao \& Fox, 2013). Ambiguous identification has hindered 
104 plans for them.

105 In this study, we aimed to improve this situation using the metabarcoding method to analyze 106 diets of these species (see flowchart in Fig. 1). By examining the efficiency of eight candidate 107 genes $(r b c \mathrm{~L}, r p o \mathrm{C} 1, r p o \mathrm{~B}, m a t \mathrm{~K}, t r n \mathrm{H}-p s b \mathrm{~A}, t r n \mathrm{~L}(\mathrm{UAA}), a t p \mathrm{~F}-a t p \mathrm{H}$, and $p s b \mathrm{~K}-p s b \mathrm{I})$, we

108

109

110

111

112

113

114

115

116

117

118

119

120

121

122

123

124

selected robust genes and corresponding primers for reference library construction and high-

throughput sequencing. Subsequently, we used the metabarcoding method to investigate diet composition of these two species based on feces collected from Shengjin Lake. Finally, we discussed and compared results from microhistology and DNA metabarcoding using the same samples to assess the utility and efficiency of these two methods.

\section{Materials and Methods}

\section{Ethics Statement}

Our research work did not involve capture or any direct manipulation or disturbances of animals.

We collected samples of plants and feces for molecular analyses. We got access to the reserve under the permission of Shengjin Lake National Nature Reserve Administration (Chizhou, Anhui, China), which is responsible for the management of the protected area and wildlife. We were forbidden to capture or disturb geese in the field.

\section{Study Area}

Shengjin Lake $\left(116^{\circ} 55^{\prime}-117^{\circ} 15^{\prime}\right.$ E, $\left.30^{\circ} 15^{\prime}-30^{\circ} 30^{\prime} \mathrm{N}\right)$ was established as a National Nature Reserve in 1997, aiming to protect waterbirds including geese, cranes and storks. The water level fluctuates greatly in this lake, with maximal water level of $17 \mathrm{~m}$ during summer (flood season) but only $10 \mathrm{~m}$ during winter (dry season). Due to this fluctuation, receding waters expose two 
125 large Carex spp. meadows and provide suitable habitats for waterbirds. This makes Shengjin

126 Lake one of the most important wintering sites for migratory waterbirds (Zhao et al., 2015).

127 Greater white-fronted goose and bean goose are the dominant herbivores wintering (from

128 October to April) in this area, accounting for $40 \%$ and $60 \%$ of populations along the East Asian -

129 Australian Flyway Route, respectively (Zhao et al., 2015).

130 Field Sampling

131 The most common plant species that these two geese may consume were collected in May 2014

132 and January 2015, especially species belonging to Carex and Poaceae. Fresh and intact leaves

133 were carefully picked, tin-packaged in the field and stored at $-80{ }^{\circ} \mathrm{C}$ in the laboratory before

134 further treatment. Morphological identification was carried out with the assistance of two

135 botanists (Profs. Zhenyu Li and Shuren Zhang from Institute of Botany, Chinese Academy of

136 Sciences).

137 All feces were collected at the reserve (Fig. 2) in January 2015. Based on previous studies

and the latest waterbird survey, sites with large flocks of geese (i.e. more than 200 individuals)

were chosen (Zhang et al., 2011). As soon as geese finished feeding and feces were defecated,

fresh droppings were picked and stored on dry ice. Droppings of bean geese were generally

thicker than those of smaller greater white-fronted goose, to the degree that these could be

reliably distinguished in the field (Zhao et al., 2015). Disposal gloves were changed for each

sample to avoid cross contamination. To avoid repeated sampling and make sure samples were

from different individuals, each sample was collected with a separation of more than $2 \mathrm{~m}$. In 
146

147 further analysis.

148 Selection of Molecular Markers and Corresponding Primers

Here, we aimed to select gene markers with adequate discriminating power for our study. We included eight chloroplast genes - $r b c \mathrm{~L}, r p o \mathrm{C} 1, r p o \mathrm{~B}, \operatorname{mat\mathrm {K}}, \operatorname{trn\mathrm {H}}-p s b \mathrm{~A}, \operatorname{trn} \mathrm{L}$ (UAA), atpF$a t p \mathrm{H}$, and $p s b \mathrm{~K}-p s b \mathrm{I}$ for estimation. Although Shengjin Lake included an array of plant species, we focused mainly on the most likely food resources (Xue et al., 2008; Zhao et al., 2015) that geese would consume for candidate gene tests. These covered 11 genera and the family Poaceae

goose. All samples were transported to laboratory on dry ice and then stored at $-80^{\circ} \mathrm{C}$ until (Table S1). For tests of all candidate genes, we recovered sequences of representative species in the selected groups from GenBank (http:/www.ncbi.nlm.nih.gov/nuccore). We calculated interspecific divergence within every genus or family based on the Kiruma 2-parameter model (K2P) using MEGA version 6 (Tamura et al., 2013). We also constructed molecular trees based on UPGMA using MEGA and characterized the resolution of species by calculating the percentage of species recovered as monophyletic based on phylogenetic trees (Rf). Secondly, primers selected out of eight candidate genes were used to amplify all specimens collected in Shengjin Lake and to check their amplification efficiency and universality. Thirdly, we calculated interspecific divergence based on sequences that we obtained from last step. Generally, a robust barcode gene is obtained when the minimal inter-specific distance exceeds the maximal intraspecific distance (e.g. existence of barcoding gaps). Finally, to allow the recognition of sequences after high-throughput sequencing, both of the forward and reverse primers of the selected marker gene were tagged specifically for each sample with 8nt nucleotide codes at the 
167 5' end (Parameswaran et al., 2007).

168

169

170

171

172

173

174

\section{DNA Extraction, Amplification and Sequencing}

Two hundred milligrams of leaf was used to extract the total DNA from each plant sample using a modified CTAB protocol (Cota-Sanchez, Remarchuk \& Ubayasena, 2006). DNA extraction of feces was carried out using the same protocol with minor modification in incubation time (elongate to $12 \mathrm{~h}$ ). Each fecal sample was crushed thoroughly and divided into four quarters. All quarters of DNA extracts were then pooled together. DNA extraction was carried out in a clean room used particularly for this study. For each batch of DNA extraction, negative controls (i.e. extraction without feces) were included to monitor possible contamination.

For plant DNA extracts, PCR amplifications were carried out in a volume of $25 \mu 1$ with $\sim 100$ ng total DNA as template, $1 \mathrm{U}$ of Taq Polymerase (Takara, Dalian, Liaoning Prov., China), 1× PCR buffer, $2 \mathrm{mM}$ of $\mathrm{Mg}^{2+}, 0.25 \mathrm{mM}$ of dNTPs, $0.1 \mu \mathrm{M}$ of forward primer and $0.1 \mu \mathrm{M}$ of reverse primer. After $4 \mathrm{~min}$ at $94{ }^{\circ} \mathrm{C}$, the PCR cycles were as follows: 35 cycles of $30 \mathrm{~s}$ at $94{ }^{\circ} \mathrm{C}$, $30 \mathrm{~s}$ at $56^{\circ} \mathrm{C}$ and $45 \mathrm{~s}$ at $72{ }^{\circ} \mathrm{C}$, and the final extension was $10 \mathrm{~min}$ at $72{ }^{\circ} \mathrm{C}$. We applied the same PCR conditions for all primers. All the successful PCR products were sequenced with Genewiz (Suzhou, Jiangsu Prov., China).

For fecal DNA extracts, PCR mixtures $(25 \mu l)$ were prepared in six replicates for each sample to reduce biased amplification. Each replicate was subjected to the same amplification procedure used for plant extracts. The six replicates of each sample were pooled and purified using the Sangon PCR product purification kit (Sangon Biotech, Shanghai, China).

Quantification was carried out to ensure equilibrium of contribution of each sample using the 
188

189

190

191

192

193

194

195

196

197

198

199

200

201

202

203

204

205

206

207

208

NanoDrop ND-2000 UV-Vis Spectrophotometer (NanoDrop Technologies, Delaware, United

States of America). High-throughput sequencing was performed using Illumina MiSeq platform

following manufacturer's instructions by BGI (Shenzhen, Guangdong Prov., China). Reads of

high-throughput sequencing could be found at NCBI's Sequence Read Archive (Accession

number: SRP070470).

\section{Data Analysis for Estimating Diet Composition}

After high-throughput sequencing, pair-ended reads were merged with the fastq_mergepairs command using usearch (http://drive5.com/usearch, Edgar, 2010). Reads were then split into independent files according to unique tags using the initial process of RDP pipeline (https://pyro.cme.msu.edu/init/form.spr). We removed sequences i) that didn't perfectly match tags and primer sequences; ii) that contained ambiguous nucleotide (N's). Tags and primers were then trimmed using the initial process of RDP pipeline. Further quality filtering using usearch discarded sequences with i) quality score less than $30(<\mathrm{Q} 30)$ and ii) length shorter than $100 \mathrm{bp}$. Unique sequences were clustered to operational taxonomy units (OTUs) at the similarity threshold of 98\% (Edgar, 2013). All OTUs were assigned to unique taxonomy with local blast 2.2.30+ (Altschul et al., 1990). We detected a plant within the reference library for each sequence with the threshold of length coverage $>98 \%$, identity $>98 \%$ and e-value $<1.0 \mathrm{e}^{-50}$. If a query sequence matched two or more taxa, it was assigned to a higher taxonomic level which included all taxa.

\section{Microhistology analysis}

We used the method described by Zhang et al. (2011) to perform microhistologic examination of 
209

210

211

212

213

214

215

216

217

218

219

220

221

222

223

224

225

226

227

228

229

fecal samples. Each sample was first washed with pure water and filtered with a $25-\mu \mathrm{m}$ filter.

Subsequently, the suspension was examined under a light microscope at $10 \times$ magnification for

quantification statistics and at $40 \times$ magnification for species identification. We compared photos

of visible fragments with an epidermis database of plants from Shengjin Lake to identify food items (Zhang et al., 2011).

\section{Results}

\section{Selection of Genes and Corresponding Primers and Reference Library Construction}

A total of 3,296 representative sequences were recovered from GenBank, ranging from 0 to 345

sequences per gene per taxon (Table S1). For Eleocharis and Trapa, only sequences of $r b c \mathrm{~L}$

gene and $\operatorname{trn} \mathrm{L}$ gene were retained, which makes it unfair to compare the efficiency and suitability

of eight candidate genes. For the other ten taxa, $\operatorname{trn} \mathrm{L}, \operatorname{trn\mathrm {H}}-p s b \mathrm{~A}, r b c \mathrm{~L}$ and $\mathrm{p} s b \mathrm{~K}-p s b \mathrm{I}$ showed

the largest inter-specific divergence in five, three, one, and one taxonomic groups, respectively.

In addition, $\operatorname{trn} \mathrm{H}-p s b \mathrm{~A}, a t p \mathrm{~F}-a t p \mathrm{H}, \operatorname{tr} n \mathrm{~L}$ and $p s b \mathrm{~K}-p s b \mathrm{I}$ showed the highest mean divergence in

four, four, one and one taxonomic groups, respectively. However, given the small number of

sequences and coverage of species, the suitability and efficiency of $a t p \mathrm{~F}-a t p \mathrm{H}$ and $p s b \mathrm{~K}-p s b \mathrm{I}$

seem to be less reliable than others. This comparison makes $t r n \mathrm{H}-p s b \mathrm{~A}$, $t r n \mathrm{~L}$ and $r b c \mathrm{~L}$ to be

selected out of the eight candidate genes. As mat $\mathrm{K}$ used to be recommended as the standard

barcode gene for Carex species (Starr, Naczi \& Chouinard, 2009), which happened to be the

dominant food for herbivorous geese in our study (Zhao et al., 2015), we included matK as a

supplement at last.

Primers for these four genes (Table 1) were used to amplify the plants that we collected in 
230 the field. In total, we collected 88 specimens in the field, belonging to 25 families, 53 genera and

23170 species (Table 2). The selected primers for $t r n \mathrm{~L}$ and $r b c \mathrm{~L}$ successfully amplified $100 \%$ and

$23291 \%$ of all species, respectively, while primers for $t r n \mathrm{H}-p s b \mathrm{~A}$ and $m a t \mathrm{~K}$ amplified only $71 \%$ and

$23343 \%$, respectively. Therefore, we chose $t r n \mathrm{~L}$ and $r b c \mathrm{~L}$ to test their discriminating power in our

234 target plants.

235 We calculated the inter-specific divergence within genera and families with at least two species to compare their discriminating power. Maximal, minimal and mean inter-specific distances were calculated for seven dominant genera and six dominant families (Table 3 ).

Neither gene could differentiate species of Vallisneria $($ mean $=0.000 \pm 0.000 \%)$ or Artemisia

$239($ mean $=0.000 \pm 0.000 \%)$. But $\operatorname{trn} L$ showed a larger divergence range for the other six genera and five families. Hence, we chose $\operatorname{trn} \mathrm{L}$ as the barcoding gene for reference library constructing and high-throughput sequencing for our study. The discriminating power of trnL was strong for most species (Table 4). However, some species could only be identified at genus-level or familylevel with trnL. For instance, five species of Potamogetonaceae shared the same sequences and this made them to be identified at genus-level. Species could be identified easily to genus and family, except for three grasses (Poaceae) Beckmannia syzigachne, Phalaris arundinacea, and Polypogon fugax which shared identical sequences.

\section{Data Processing for Estimating Diet Composition}

In total, 0.21 and 0.18 million reads were generated for greater white-fronted goose (GWFG) and 
251 Shengjin Lake reference database. Finally, with DNA metabarocoding, 12 items were discovered

252 in the feces of GWFG, including one at family-level, three at genus-level and eight at species-

253 level (Table 6). Four items were discovered in the feces of BG, including one at genus-level and

254 three at species-level. In total, this method identified 15 taxa in feces of these geese.

255 However, the sequence percentage of each food item varied greatly (Table 6). For GWFG,

256 the majority of sequences (96.36\%) were composed of only five items - Poaceae spp. (47.98\%,

257 except Poa annua), Poa annua (21.86\%), Carex heterolepis (17.51\%), Carex spp. (9.01\%,

258 except Carex heterolepis), and Alopecurus aequalis (3.21\%). For BG, almost all the sequences

259 belonged to Carex heterolepis (99.49\%). Other items only occupied a relatively small proportion

260 of sequences. In addition, the presence of each item per sample was also unequal (Table S2). For

261 example in GWFG, Carex heterolepis, Carex spp., Poa annua and Potentilla supina were

262 present in almost all the samples, while Stellaria media, Asteraceae sp. and Lapsana

263 apogonoldes occurred in only about one third of samples.

264 When microhistologic examination were performed using the same samples, eight items

265 were found in the feces of greater white-fronted goose, including one at family-level, four at

266 genus-level and three at species-level (Table 6). Dominant items were Poaceae spp. (45.68\%),

267 Alopecurus Linn. (30.93\%) and Carex heterolepis (16.39\%). Seven items were found in the feces

268 of bean goose, including four at genus-level and three at species-level (Table 6). Dominant items

269 were Carex heterolepis (62.85\%), Asteraceae sp. (14.55\%), and Alopecurus Linn. (13.18\%).

Discussion 
272 With greatly reduced cost, extremely high throughput and information content, metabarcoding

273 has revolutionized the exploration and quantification of dietary analysis with noninvasive

274 samples containing degraded DNA (Fonseca et al., 2010; Shokralla et al., 2014). Despite

275 enormous potential to boost data acquisition, successful application of this technology relies

276 greatly on the power and efficiency of genetic markers and corresponding primers (Bik et al.,

277 2012; Zhan et al., 2014). In order to select the most appropriate marker gene for our study, we

278 compared the performance of eight commonly used chloroplast genes, $r b c \mathrm{~L}, r p o \mathrm{~B}, r p o \mathrm{C} 1$, matK,

$279 \operatorname{trn} \mathrm{L}, \operatorname{trn} \mathrm{H}-p s b \mathrm{~A}, a t p \mathrm{~F}-a t p \mathrm{H}$, and $p s b \mathrm{~K}-p s b \mathrm{I}$ and their corresponding primers. Although a higher

280 level of discriminating power was shown in several studies, atpF-atpH and $p s b \mathrm{~K}-p s b \mathrm{I}$ were not

281 as commonly used as other barcoding genes (Hollingsworth, Graham \& Little, 2001). As one of

282 the most rapidly evolving coding genes of plastid genomes, mat $\mathrm{K}$ was considered as the closest

283 plant analogue to the animal barcode COI (Hilu \& Liang, 1997). However, matK was difficult to

284 amplify using available primer sets, with only $43 \%$ of successful amplification in this study. In

285 spite of the higher species discrimination success of $t r n \mathrm{H}-p s b \mathrm{~A}$ than $r b c \mathrm{~L}+m a t \mathrm{~K}$ in some groups,

286 the presence of duplicated loci, microinversions and premature termination of reads by

287 mononucleotide repeats lead to considerable proportion of low-quality sequences and over-

288 estimation of genetic difference when using trnH-psbA (Graham et al., 2000; Whitlock Hale \&

289 Groff, 2010). In contrast, the barcode region of $r b c \mathrm{~L}$ is easy to amplify, sequence, and align in

290 most plants and was recommended as the standard barcode for land plants (Chase et al., 2007).

291 The relatively modest discriminating power (compared to trnL) precludes its application for our

292 study aiming to recover high resolution of food items. Consequently, trnL was selected out of 
293

294

295

296

297

298

299

300

301

302

303

304

305

306

307

308

309

310

311

312

313

eight candidate markers, with $100 \%$ amplification success, more than $90 \%$ of high quality sequences, and relatively large inter-specific divergence.

One of the biggest obstacles in biodiversity assessment and dietary analysis is the lack of a comprehensive reference library, without which it is impossible to accurately interpret and assign sequences generated from high-throughput sequencing (Valentini, Pompanon \& Taberlet 2009;

Barco et al., 2015). In this study, we constructed a local reference library by amplifying the most common species (70 morpho-species in total) during the wintering period with the trnL gene.

Although not all of them could be identified at species-level with $\operatorname{trn} \mathrm{L}$ due to relatively low interspecific divergence, many species could be separated with distinctive sequences. Previous studies have recommended group-specific barcodes to differentiate closely related plants at the species level (Li et al., 2015). For instance, matK has been proved to be more efficient for the discrimination of Carex spp. (Starr, Naczi \& Chouinard, 2009). However, the primer set of matK failed to amplify species of Carex spp. in our study, suggesting the universality of selected primer pairs should be tested in each study (Zhan et al., 2014).

\section{Applications of Metabarcoding for Geese Diet Analysis}

A variety of recent studies have demonstrated the great potential of metabarcoding for dietary analysis, mainly owing to the high throughput, high discriminating power, and the ability to process large-scale samples simultaneously (Creer et al., 2010; Taberlet et al., 2012; Shehzad et al., 2012). In this study, we applied this method to recover diets of herbivorous geese and provided standard protocols for dietary analysis of these two ecologically important waterbirds.

Our results further proved the more objective, less experience-dependent and more time-efficient 
314 character of DNA metabarcoding. However, not all the species in the reference library could be 315 identified at species-level, owing to low inter-specific divergence. We suggest that multiple 316 group-specific markers to be incorporated in the future, as in De Barba et al. (2014). Two

317 species, Carex thunbergii and Fabaceae sp., were only discovered via microhistologic analysis rather than metabarcoding. This failure might reflect the biased fragment amplification of current technology, of which dominant templates could act as inhibitors of less dominant species (Piñol et al., 2015). However, three species of Poaceae were only discovered using metabarcoding. In total, more taxa and higher resolution were attained using metabarcoding. But microhistology still proved a powerful supplementary. Previous studies using metabarcoding usually detected dozens of food items, even as many as more than one hundred species. For instance, 18 taxa prey were identified for leopard cat (Prionailurus bengalensis) (Shehzad et al., 2012); 44 plant taxa were recovered in feces of red-headed wood pigeon (Columba janthina nitens) (Ando et al., 2013); while more than 100 taxa were found in diet studies of brown bear (Ursus arctos) (De

Barba et al., 2014). The relatively narrow diet spectrum of herbivorous geese may lead to misunderstanding that this result of our study is merely an artefact due to small sampling effort.

However, this result is credible since these two geese species only feed on Carex meadow, where the dominant vegetation is Carex spp., with other species such as Poaceae and dicots (Zhao et al., 2015). Even though other wetland plants exist, they usually composed only a small proportion of the geese diets. 
335

336

337

sequences in this study were in accord with microhistologic observations, which was considered an efficient way to provide quantitative results (Wang et al., 2013). Discrepancies might come from the semi-quantitative nature of metabarcoding methods (Sun et al., 2015). This is likely derived from PCR amplification, which always entails biases caused by universal primertemplate mismatches, annealing temperature or number of PCR cycles (Zhan et al., 2014; Piñol et al., 2015). Other methods such as shot-gun sequencing or metagenomic sequencing could be incorporated in the future to give information on abundances of food items (Srivathsan et al., 2015).

\section{Implications for Waterbird Conservation and Wetland Management}

For long-distance migratory waterbirds, such as the wild geese in this study, their abundance and distribution are greatly influenced by diet availability and habitat use (Wang et al., 2013). For example, waterbirds may be restricted at (forced to leave) certain areas due to favoring (loss) of particular food (Wang et al., 2013), while the recovery of such food may contribute to return of bird populations (Noordhuis et al., 2002). Results of both metabarcoding and microhistologic analysis in this study revealed that Carex and Poaceae were dominant food components which is in accordance with previous studies. The increasing number of these two geese wintering at the Shengjin Lake may be attributed to the expansion of Carex meadow, which offers access to abundant food resources (Zhao et al., 2015). Considering the long-distance migratory character of these birds, it is important to maintain energy balances and good body conditions in wintering areas because this might further influence their departure dates and reproductive success after arriving at breeding areas (Prop, Black \& Shimmings, 2003). Based on this, it is important for 
356

357

358

359

360

361

362

363

364

365

366

367

368

369

370

371

372

373

374

375

376

wetland managers to maintain the suitable habitats and food resources for sustainable conservation of waterbirds, which highlights the significance of diet information. Our study also indicated that overlap and dissimilarity existed between the diets of these two geese. Animals foraging in the same habitats may compete for limited food resources (Madsen \& Mortensen, 1987). This discrepancy of food composition may arise from the avoidance of inter-specific competition (Zhao et al., 2015). However, with the increase of these two species in Shengin Lake, further research is needed to investigate the mechanisms of food resource partitioning and spatial distribution.

Shengjin Lake is one of the most important wintering sites for tens of thousands of migratory watebirds, while annual life cycles of these birds depend on the whole migratory route, including breeding sites, stop-over sites and wintering sites (Kear, 2006). Thus, a molecular reference library covering all the potential food items along the whole migratory route will be useful both for understanding of wetland connections and waterbird conservation. Besides, the ability of DNA metabarcoding to process lots of samples simultaneously enables rapid analyses and makes this method helpful for waterbird studies.

\section{Acknowledgements}

We are very grateful to the stuff of the Shengjin Lake National Nature Reserve for their excellent assistance during the field work. Great thanks to Zhujun Wang and An An for feces collection in the field. We thank Song Yang for collecting plants in the Shengjin Lake Reserve. We also thank Profs. Zhenyu Li and Shuren Zhang for plant identification. Special thanks to Drs. Meijuan Zhao, Xin Wang, Fanjuan Meng and Peihao Cong for preparing the epidermis database and 
377 guiding microhistologic analysis. 
378

379

380

381

382

383

384

385

386

387

388

389

390

391

392

393

394

395

396

397

398

399

400

401

402

403

404

405

406

407

408

409

410

411

412

413

414

415

416

417

418

\section{References}

Altschul SF, Gish W, Miller W, Myers EW, Lipman DJ. 1990. Basic local alignment search tool. Journal of Molecular Biology 215:403-410 DOI 10.1006/jmbi.1990.9999.

Álvarez I, Wendel JF. 2003. Ribosomal ITS sequences and plant phylogenetic inference. Molecular Phylogenetics and Evolution 29:417-434 DOI 10.1016/S1055-7903(03)00208-2.

Ando H, Setsuko S, Horikoshi K, Suzuki H, Umehara S, Inoue-Murayama M, Isagi Y. 2013. Diet analysis by next - generation sequencing indicates the frequent consumption of introduced plants by the critically endangered red - headed wood pigeon (Columba janthina nitens) in oceanic island habitats. Ecology and Evolution 3:4057-4069 DOI 10.1002/ece3.773.

Barco A, Raupach MJ, Laakmann S, Neumann H, Knebelsberger T. 2015. Identification of North Sea molluscs with DNA barcoding. Molecular Ecology Resources 16:288-297 DOI 10.1111/17550998.12440.

Bik HM, Porazinska DL, Creer S, Caporaso JG, Knight R, Thomas WK. 2012. Sequencing our way towards understanding global eukaryotic biodiversity. Trends in Ecology and Evolution 27:233-243 DOI 10.1016/j.tree.2011.11.010.

Bohmann K, Evans A, Gilbert MTP, Carvalho GR, Creer S, Knapp M, Yu WD, de Bruyn M. 2014. Environmental DNA for wildlife biology and biodiversity monitoring. Trends in Ecology and Evolution 29:358-367 DOI 10.1016/j.tree.2014.04.003.

Brander LM, Florax, RJ, Vermaat JE. 2006. The empirics of wetland valuation: a comprehensive summary and a meta-analysis of the literature. Environmental and Resource Economics 33:223-250. DOI 10.1007/s10640-005-3104-4.

Chase MW, Cowan RS, Hollingsworth PM, van den Berg C, Madriñán S, Petersen G, Seberg O, Jorgsensen T, Cameron KM, Carine M, Pedersen N, Hedderson TAJ, Conrad F, Salazar GA, Richardson JE, Hollingsworth M, Barraclough TG, Kelly L, Wilkinson M. 2007. A proposal for a standardised protocol to barcode all land plants. Taxon 56:295-299.

Cota-Sanchez JH, Remarchuk K, Ubayasena K. 2006. Ready-to-use DNA extracted with a CTAB method adapted for herbarium specimens and mucilaginous plant tissue. Plant Molecular Biology Reporter 24:161-167 DOI 10.1007/BF02914055.

Creer S, Fonseca VG, Porazinska DL, Giblin-Davis RM, Sung W, Power DM, Packer M, Carvalho GR, Blaxter ML, Lambshead PJD, Thomas WK. 2010. Ultrasequencing of the meiofaunal biosphere: practice, pitfalls and promises. Molecular Ecology 19:4-20 DOI 10.1111/j.1365-294X.2009.04473.x.

De Barba M, Miquel C, Boyer F, Mercier C, Rioux D, Coissac E, Taberlet P. 2014. DNA metabarcoding multiplexing and validation of data accuracy for diet assessment: application to omnivorous diet. Molecular Ecology Resources 14:306-323 DOI 10.1111/1755-0998.12188.

Deagle BE, Kirkwood R, Jarman SN. 2009. Analysis of Australian fur seal diet by pyrosequencing prey DNA in faeces. Molecular Ecology 18:2022-2038 DOI 10.1111/j.1365-294X.2009.04158.x.

Dunning LT, Savolainen V. 2010. Broad-scale amplification of matK for DNA barcoding plants, a technical note. Botanical Journal of the Linnean Society 164:1-9.

Edgar RC. 2010. Search and clustering orders of magnitude faster than BLAST. Bioinformatics 26:2460-2461 DOI 10.1093/bioinformatics/btq461.

Edgar RC. 2013. UPARSE: highly accurate OTU sequences from microbial amplicon reads. Nature Methods 
10:996-998 DOI 10.1038/NMETH.2604.

Elliott TL, Jonathan Davies T. 2014. Challenges to barcoding an entire flora. Molecular Ecology Resources 14:883-891 DOI 10.1111/1755-0998.12277.

Fazekas AJ, Burgess KS, Kesanakurti PR, Graham SW, Newmaster SG, Husband BC, Percy DM, Hajibabaei M, Barrett SC. 2008. Multiple multilocus DNA barcodes from the plastid genome discriminate plant species equally well. PLoS One 3:e2802 DOI 10.1371/journal.pone.0002802.

Fonseca VG, Carvalho GR, Sung W, Johnson HF, Power DM, Neill SP, Packer M, Blaxter ML, Labmshead PJD, Thomas WK, Creer S. 2010. Second-generation environmental sequencing unmasks marine metazoan biodiversity. Nature Communications 1:98 DOI 10.1038/ncomms1095.

Ford CS, Ayres KL, Haider N, Toomey N, van-Alpen-Stohl J. 2009. Selection of candidate DNA barcoding regions for use on land plants. Botanical Journal of the Linnean Society 159:1-11 DOI 10.1111/j.10958339.2008.00938.x.

Fox AD, Bergersen E, Tombre IM, Madsen J. 2007. Minimal intra-seasonal dietary overlap of barnacle and pink-footed geese on their breeding grounds in Svalbard. Polar Biology 30:759-768 DOI 10.1007/s00300-006-0235-1.

Fox AD, Cao L, Zhang Y, Barter M, Zhao M, Meng F, Wang S. 2011. Declines in the tuber-feeding waterbird guild at Shengjin Lake National Nature Reserve, China-a barometer of submerged macrophyte collapse. Aquatic Conservation: Marine and Freshwater Ecosystems 21:82-91 DOI 10.1002/aqc.1154.

Graham SW, Reeves PA, Burns AC, Olmstead RG. 2000. Microstructural changes in noncoding chloroplast DNA: interpretation, evolution, and utility of indels and inversions in basal angiosperm phylogenetic inference. International Journal of Plant Sciences 161:S83-S96 DOI 10.1086/317583.

Hibert F, Taberlet P, Chave J, Scotti-Saintagne C, Sabatier D, Richard-Hansen C. 2013. Unveiling the diet of elusive rainforest herbivores in next generation sequencing era? The tapir as a case study. PloS One 8: e60799 DOI 10.1371/journal.pone.0060799.

Hilu KW, Liang H. 1997. The matK gene: sequence variation and application in plant systematics. American Journal of Botany 84:830-839 DOI 10.2307/2445819.

Hollingsworth PM, Graham SW, Little DP. 2011. Choosing and using a plant DNA barcode. PloS One 6:e19254 DOI 10.1371/journal.pone.0019254.

James HF, Burney DA. 1997. The diet and ecology of Hawaii's extinct flightless waterfowl: evidence from coprolites. Biological Journal of the Linnean Society 62:279-297 DOI 10.1111/j.10958312.1997.tb01627.x.

Kear J. 2005. Ducks, geese and swans. Oxford: Oxford University Press.

Kress WJ, Erickson DL, Jones FA, Swenson NG, Perez R, Sanjur O, Bermingham E. 2009. Plant DNA barcodes and a community phylogeny of a tropical forest dynamics plot in Panama. Proceedings of the National Academy of Sciences of the United States of America 106:18621-18626 DOI 10.1073/pnas.0909820106.

Li X, Yang Y, Henry RJ, Rossetto M, Wang Y, Chen S. 2015. Plant DNA barcoding: from gene to genome. Biological Reviews 90:157-166 DOI 10.1111/brv.12104.

Ma Z, Cai Y, Li B, Chen J. 2010. Managing wetland habitats for waterbirds: an international perspective. Wetlands 30:15-27 DOI 10.1007/s13157-009-0001-6.

Madsen J, Mortensen CE. 1987. Habitat exploitation and interspecific competition of moulting geese in East 
Greenland. Ibis 129:25-44 DOI 10.1111/j.1474-919X.1987.tb03157.x.

Noordhuis R, van der Molen DT, van den Berg MS. 2002. Response of herbivorous water-birds to the return of Chara in Lake Veluwemeer, The Netherlands. Aquatic Botany 72:349-367 DOI 10.1016/S03043770(01)00210-8.

Parameswaran P, Jalili R, Tao L, Shokralla S, Gharizadeh B, Ronaghi M, Fire AZ. 2007. A pyrosequencing-tailored nucleotide barcode design unveils opportunities for large-scale sample multiplexing. Nucleic Acids Research 35:e130 DOI 10.1093/nar/gkm760.

Piñol J, Mir G, Gomez-Polo P, Agust1 N. 2015. Universal and blocking primer mismatches limit the use of high-throughput DNA sequencing for the quantitative metabarcoding of arthropods. Molecular Ecology Resources 15:819-830 DOI 10.1111/1755-0998.12355.

Pompanon F, Deagle BE, Symondson WO, Brown DS, Jarman SN, Taberlet P. 2012. Who is eating what: diet assessment using next generation sequencing. Molecular Ecology 21:1931-1950 DOI 10.1111/j.1365-294X.2011.05403.x.

Prop J, Black JM, Shimmings P. 2003. Travel schedules to the high arctic: barnacle geese trade - off the timing of migration with accumulation of fat deposits. Oikos 103:403-414 DOI 10.1034/j.16000706.2003.12042.x.

Rayé G, Miquel C, Coissac E, Redjadj C, Loison A, Taberlet P. 2011. New insights on diet variability revealed by DNA barcoding and high-throughput sequencing: chamois diet in autumn as a case study. Ecological Research 26:265-276 DOI 10.1007/s11284-010-0780-5.

Reynolds C, Miranda NA, Cumming GS. 2015. The role of waterbirds in the dispersal of aquatic alien and invasive species. Diversity and Distributions 21:744-754 DOI 10.1111/ddi.12334.

Samelius G, Alisauskas RT. 1999. Diet and growth of glaucous gulls at a large Arctic goose colony. Canadian Journal of Zoology 77:1327-1331 DOI 10.1139/z99-091.

Sang T, Crawford DJ, Stuessy TF. 1997. Chloroplast DNA phylogeny, reticulate evolution, and biogeography of Paeonia (Paeoniaceae). American Journal of Botany 84:1120-1136.

Shehzad W, Riaz T, Nawaz MA, Miquel C, Poillot C, Shah SA, Pompanon F, Coissac E, Taberlet P. 2012. Carnivore diet analysis based on next-generation sequencing: application to the leopard cat (Prionailurus bengalensis) in Pakistan. Molecular Ecology 21:1951-1965 DOI 10.1111/j.1365294X.2011.05424.x.

Shokralla S, Spall JL, Gibson JF. 2012. Next-generation sequencing technologies for environmental DNA research. Molecular Ecology 21:1794-1805 DOI 10.1111/j.1365-294X.2012.05538.x.

Srivathsan A, Sha J, Vogler AP, Meier R. 2015. Comparing the effectiveness of metagenomics and metabarcoding for diet analysis of a leaf-feeding monkey (Pygathrix nemaeus). Molecular Ecology Resources 15:250-261 DOI 10.1111/1755-0998.12302.

Starr JR, Naczi RFC, Chouinard BN. 2009. Plant DNA barcodes and species resolution in sedge (Carex, Cyperaceae). Molecular Ecology Resources 9:151-163 DOI 10.1111/j.1755-0998.2009.02640.x.

Sun C, Zhao Y, Li H, Dong Y, MacIsaac HJ, Zhan A. 2015. Unreliable quantification of species abundance based on high-throughput sequencing data of zooplankton communities. Aquatic Biology 24:9-15 DOI $10.3354 / \mathrm{ab} 00629$.

Swennen C, Yu YT. 2005. Food and feeding behavior of the Black-faced Spoonbill. Waterbirds 28:19-27 DOI 10.1675/1524-4695(2005)028[0019:FAFBOT]2.0.CO;2. 
501

502

503

504

505

506

507

508

509

510

511

512

513

514

515

516

517

518

Symondson WOC. 2002. Molecular identification of prey in predator diets. Molecular Ecology 11:627-641 DOI 10.1046/j.1365-294X.2002.01471.x.

Taberlet P, Coissac E, Pompanon F, Brochmann C, Willerslev E. 2012. Towards next-generation biodiversity assessment using DNA metabarcoding. Molecular Ecology 21:2045-2050 DOI 10.1111/j.1365-294X.2012.05470.x.

Taberlet P, Coissac E, Pompanon F, Gielly L, Miquel C, Valentini A, Vermat T, Corthier G, Brocmann C, Willerslev E. 2007. Power and limitations of the chloroplast trnL (UAA) intron for plant DNA barcoding. Nucleic Acids Research 35:e14 DOI 10.1093/nar/gk1938.

Taberlet P, Gielly L, Pautou G, Bouvet J. 1991. Universal primers for amplification of three non-coding regions of chloroplast DNA. Plant Molecular Biology 17: 1105-1109 DOI 10.1007/BF00037152.

Tamura K, Stecher G, Peterson D, Filipski A, Kumar S. 2013. MEGA6: molecular evolutionary genetics analysis version 6.0. Molecular Biology and Evolution 30:2725-2729 DOI 10.1093/molbev/mst 197.

Tate JA, Simpson BB. 2003. Paraphyly of Tarasa (Malvaceae) and diverse origins of the polyploidy species. Systematic Botany 28:723-737.

Valentini A, Pompanon F, Taberlet P. 2009. DNA barcoding for ecologists. Trends in Ecology and Evolution 24:110-117 DOI 10.1016/j.tree.2008.09.011.

Wang X, Fox AD, Cong P, Barter M, Cao L. 2012. Changes in the distribution and abundance of wintering Lesser White-fronted Geese Anser erythropus in eastern China. Bird Conservation International 22:128134 DOI 10.1017/S095927091100030X.

Wang X, Fox AD, Cong P, Cao L. 2013. Food constraints explain the restricted distribution of wintering Lesser White-fronted Geese Anser erythropus in China. Ibis 155:576-592 DOI 10.1111/ibi.12039.

Whitlock BA, Hale AM, Groff PA. 2010. Intraspecific inversions pose a challenge for the $t r n \mathrm{H}-p s b \mathrm{~A}$ plant DNA barcode. PLoS One 5:e11533 DOI 10.1371/journal.pone.0011533.

Wolfe KH, Li WH, Sharp PM. 1987. Rates of nucleotide substitution vary greatly among plant mitochondrial, chloroplast, and nuclear DNAs. Proceedings of the National Academy of Sciences of the United States of America 84:9054-9058 DOI 10.1073/pnas.84.24.9054.

Xu C, Dong W, Shi S, Cheng T, Li C, Liu Y, Wu P, Wu H, Gao P, Zhou S. 2015. Accelerating plant DNA barcode reference library construction using herbarium specimens: improved experimental techniques. Molecular Ecology Resources 15:1366-1374 DOI 10.1111/1755-0998.12413.

Xu L, Xu W, Sun Q, Zhou Z, Shen J, Zhao X. 2008. Flora and vegetation in Shengjin Lake. Journal of Wuhan Botanical Research 27:264-270.

Zhan A, Bailey SA, Heath DD, Macisaac HJ. 2014. Performance comparison of genetic markers for highthroughput sequencing-based biodiversity assessment in complex communities. Molecular Ecology Resources 14:1049-1059 DOI 10.1111/1755-0998.12254.

Zhan A, MacIsaac HJ. 2015. Rare biosphere exploration using high-throughput sequencing: research progress and perspectives. Conservation Genetics 16:513-522 DOI 10.1007/s10592-014-0678-9.

Zhang Y, Cao L, Barter M, Fox AD, Zhao M, Meng F, Shi H. 2011. Changing distribution and abundance of Swan Goose Anser cygnoides in the Yangtze River floodplain: the likely loss of a very important wintering site. Bird Conservation International 21:36-48 DOI 10.1017/S0959270910000201.

Zhao M, Cao L, Fox AD. 2013. Distribution and diet of wintering Tundra Bean Geese Anser fabalis serrirostris at Shengjin Lake, Yangtze River floodplain, China. Wildfow 60:52-63. 
542 Zhao M, Cao L, Klaassen M, Zhang Y, Fox AD. 2015. Avoiding competition? Site use, diet and foraging 543 behaviours in two similarly sized geese wintering in China. Ardea 103:27-38 DOI $544 \quad$ 10.5253/arde.v103i1.a3.

545 Zhao M, Cong P, Barter M, Fox AD, Cao L. 2012. The changing abundance and distribution of Greater 546 White-fronted Geese Anser albifrons in the Yangtze River floodplain: impacts of recent hydrological changes. Bird Conservation International 22:135-143 DOI 10.1017/S0959270911000542. 


\section{Table $\mathbf{1}$ (on next page)}

Primers of candidate genes and reference library constructing.

Only the $\mathrm{c}$ and $h$ were used for high-throughput sequencing in fusion primer mode (primer + tags). The unique tags were used to differentiate PCR products pooled together for highthroughput sequencing (Parameswaran et al., 2007). 


\begin{tabular}{|l|l|l|}
\hline Gene & Primer & Sequence $\left(5^{\prime}-3^{\prime}\right)$ \\
\hline$m a t \mathrm{~K}$ & matK-XF & TAATTTACGATCAATTCATTC \\
\hline & matK-MALP & ACAAGAAAGTCGAAGTAT \\
\hline$r b c \mathrm{~L}$ & rbcLa-F & ATGTCACCACAAACAGAGACTAAAGC \\
\hline & rbcLa- ${ }^{\mathrm{d}}$ & GTAAAATCAAGTCCACCRCG \\
\hline & pasbA3_f ${ }^{\mathrm{e}}$ & CGCGCATGGTGGATTCACAATCC \\
\hline$t r n \mathrm{~L} s b \mathrm{~A}$ & trnHf_05 & GTTATGCATGAACGTAATGCTC \\
\hline & $\mathrm{c}^{\mathrm{g}}$ & CGAAATCGGTAGACGCTACG \\
\hline & $\mathrm{h}^{\mathrm{h}}$ & CCATTGAGTCTCTGCACCTATC \\
\hline
\end{tabular}

1 Footnotes: "a" referred to "Ford et al., 2009"; "b" referred to "Dunning \& Savolainen, 2010"; "c" referred to

2 "Hasebe et al., 1994"; "d" referred to "Kress et al., 2009"; "e" referred to "Tate \& Simpson, 2003"; "f" referred 3 to "Sang, Crawfor \& Stuessy, 1997"; "g" referred to "Taberlet et al., 1991"; "h" referred to "Taberlet et al., 4 2007". 
Table 2 (on next page)

Plant species in the reference library.

We collected these samples from Shengjin Lake. 


\begin{tabular}{|c|c|c|c|}
\hline Species & $\begin{array}{c}\text { No. of } \\
\text { samples }\end{array}$ & Species & $\begin{array}{c}\text { No. of } \\
\text { samples }\end{array}$ \\
\hline Curculigo orchioides & 1 & Trapella sinensis & 2 \\
\hline Artemisia capillaris & 1 & Plantago asiatica & 1 \\
\hline Artemisia selengensis & 2 & Alopecurus aequalis & 2 \\
\hline Aster subulatus & 1 & Beckmannia syzigachne & 1 \\
\hline Bidens frondosa & 1 & Bromus japonicus & 1 \\
\hline Erigeron annuus & 1 & Cynodon dactylon & 2 \\
\hline Gnaphalium affine & 1 & Phalaris arundinacea & 1 \\
\hline Hemistepta lyrata & 1 & Phragmites australis & 1 \\
\hline Kalimeris incisa & 1 & Pоа аппиа & 1 \\
\hline Bothriospermum kusnezowii & 1 & Polypogon fugax & 1 \\
\hline Lobelia chinensis & 1 & Roegneria kamoji & 2 \\
\hline Sagina japonica & 1 & Zizania latifolia & 1 \\
\hline Stellaria media & 2 & Polygonum lapathifolium & 4 \\
\hline Calystegia hederacea & 1 & Polygonum orientale & 1 \\
\hline Cardamine lyrata & 1 & Polygonum perfoliatum & 1 \\
\hline Carex heterolepis & 3 & Polygonum persicaria & 1 \\
\hline Carex capricornis & 1 & Rumex trisetiferus & 3 \\
\hline Carex paxii & 1 & Potamogeton crispus & 1 \\
\hline Carex remotiuscula & 1 & Potamogeton maackianus & 1 \\
\hline Fimbristylis dichotoma & 1 & Potamogeton malaianus & 1 \\
\hline Eleocharis migoana & 1 & Potamogeton natans & 1 \\
\hline Scripus karuizawensis & 1 & Potamogeton pectinatus & 1 \\
\hline Nymphoides peltatum & 1 & Clematis florida & 1 \\
\hline Myriophyllum spicatum & 1 & Ranunculus chinensis & 2 \\
\hline Hydrilla verticillta & 1 & Ranunculus sceleratus & 2 \\
\hline Hydrocharis dubia & 1 & Potentilla freyniana & 2 \\
\hline Vallisineria spiralis & 1 & Gratiola japonica & 1 \\
\hline Vallisneria spinulosa & 1 & Mazus miquelii & 2 \\
\hline Juncus effusus & 1 & Veronica undulata & 1 \\
\hline Juncus gracillimus. & 1 & Trapa bispinosa & 1 \\
\hline Leonurus japonicus & 1 & Trapa maximowiczii & 1 \\
\hline Salvia plebeia & 1 & Trapa pseudoincisa & 1 \\
\hline Glycine soja & 1 & Trapa quadrispinosa & 1 \\
\hline Vicia sativa & 1 & Hydrocotyle sibthorpioides & 1 \\
\hline Euryale ferox & 1 & Torilis japonica & 2 \\
\hline
\end{tabular}




\section{Table 3(on next page)}

Inter-specific divergences within dominant genera and families of $r b c \mathrm{~L}$ gene and $\operatorname{trn} \mathrm{L}$ gene with Kiruma 2-Parameter model.

Underscores indicate the most common food composition based on earlier microhistologic analysis (Zhao et al., $2012 \&$ 2015). 


\begin{tabular}{|c|c|c|c|c|c|c|c|}
\hline \multirow{2}{*}{$\begin{array}{l}\text { Inter-specific } \\
\text { divergence }\end{array}$} & \multirow{2}{*}{ Taxa } & \multicolumn{3}{|c|}{$r b c \mathrm{~L}$} & \multicolumn{3}{|c|}{$\operatorname{trn} \mathrm{L}$} \\
\hline & & maximal & minimal & mean & maximal & minimal & mean \\
\hline \multirow{7}{*}{ Within genera } & Artemisia & 0.000 & 0.000 & $0.000 \pm 0.000$ & 0.000 & 0.000 & $0.000 \pm 0.000$ \\
\hline & Carex & $\underline{0.013}$ & $\underline{0.000}$ & $\underline{0.008 \pm 0.006}$ & $\underline{0.058}$ & $\underline{0.000}$ & $\underline{0.027 \pm 0.021}$ \\
\hline & Polygonum & 0.027 & 0.000 & $0.010 \pm 0.006$ & 0.076 & 0.000 & $0.033 \pm 0.022$ \\
\hline & Potamogeton & 0.012 & 0.000 & $0.005 \pm 0.0034$ & 0.016 & 0.000 & $0.005 \pm 0.005$ \\
\hline & Ranunculus & 0.031 & 0.000 & $0.020 \pm 0.009$ & 0.042 & 0.021 & $0.024 \pm 0.022$ \\
\hline & Trapa & $\underline{0.000}$ & $\underline{0.000}$ & $\underline{0.000 \pm 0.000}$ & $\underline{0.081}$ & $\underline{0.000}$ & $\underline{0.049 \pm 0.030}$ \\
\hline & Vallisneria & 0.000 & 0.000 & $0.000 \pm 0.000$ & 0.000 & 0.000 & $0.000 \pm 0.000$ \\
\hline \multirow{6}{*}{$\begin{array}{l}\text { Within } \\
\text { families }\end{array}$} & Cyperaceae & $\underline{0.043}$ & $\underline{0.000}$ & $\underline{0.018 \pm 0.010}$ & $\underline{0.178}$ & $\underline{0.000}$ & $\underline{0.084 \pm 0.046}$ \\
\hline & Asteraceae & 0.120 & 0.000 & $0.049 \pm 0.017$ & 0.087 & 0.000 & $0.023 \pm 0.018$ \\
\hline & Poaceae & $\underline{0.025}$ & $\underline{0.000}$ & $\underline{0.016 \pm 0.0009}$ & $\underline{0.166}$ & $\underline{0.000}$ & $\underline{0.074 \pm 0.039}$ \\
\hline & Hydrocharitaceae & 0.122 & 0.000 & $0.078 \pm 0.020$ & 0.159 & 0.000 & $0.100 \pm 0.054$ \\
\hline & Polygonaceae & 0.043 & 0.000 & $0.020 \pm 0.009$ & 0.129 & 0.000 & $0.031 \pm 0.022$ \\
\hline & Ranunculaceae & 0.033 & 0.016 & $0.017 \pm 0.015$ & 0.045 & 0.000 & $0.018 \pm 0.013$ \\
\hline
\end{tabular}




\section{Table 4 (on next page)}

Number of species and unique sequences for families with more than one species in Shengjin Lake plant database. 


\begin{tabular}{|l|c|c|}
\hline Family & No. of Species & No. of Sequences \\
\hline Asteraceae & 8 & 7 \\
\hline Caryophyllaceae & 2 & 2 \\
\hline Cyperaceae & 7 & 5 \\
\hline Fabaceae & 2 & 2 \\
\hline Hydrocharitaceae & 4 & 3 \\
\hline Lamiaceae & 2 & 2 \\
\hline Poaceae & 10 & 8 \\
\hline Polygonaceae & 5 & 5 \\
\hline Potamogetonaceae & 5 & 1 \\
\hline Ranunculaceae & 3 & 3 \\
\hline Scrophulariaceae & 3 & 3 \\
\hline Trapaceae & 4 & 3 \\
\hline Umbelliferae & 2 & 2 \\
\hline
\end{tabular}




\section{Table 5 (on next page)}

Summary of the process and results of high-throughput sequencing analysis.

GWFG = Greater white-fronted goose; BG = Bean goose . 


\begin{tabular}{|c|c|c|c|c|c|}
\hline Sample & $\begin{array}{c}\text { Pair-end } \\
\text { sequences }\end{array}$ & $\begin{array}{c}\text { Sequences for which primers } \\
\text { and tags were identified and } \\
\text { with length }>100 \mathrm{bp}\end{array}$ & $\begin{array}{c}\text { Unique } \\
\text { sequences }\end{array}$ & OTUs & $\begin{array}{c}\text { Food } \\
\text { items }\end{array}$ \\
\hline GWFG1 & 16303 & 8627 & 1288 & 78 & 8 \\
\hline GWFG2 & 25482 & 13449 & 1091 & 102 & 8 \\
\hline GWFG3 & 19063 & 10056 & 1277 & 48 & 10 \\
\hline GWFG4 & 23856 & 12548 & 1419 & 114 & 8 \\
\hline GWFG5 & 20955 & 11249 & 1720 & 123 & 9 \\
\hline GWFG6 & 11677 & 7205 & 973 & 52 & 9 \\
\hline GWFG7 & 13377 & 6782 & 1328 & 59 & 9 \\
\hline GWFG8 & 7749 & 3959 & 774 & 89 & 9 \\
\hline GWFG9 & 16833 & 8799 & 1436 & 90 & 6 \\
\hline GWFG10 & 18474 & 9819 & 449 & 32 & 9 \\
\hline GWFG11 & 19648 & 10458 & 617 & 31 & 6 \\
\hline BG1 & 20225 & 10254 & 784 & 23 & 4 \\
\hline BG2 & 14195 & 7161 & 564 & 16 & 2 \\
\hline BG3 & 2229 & 1149 & 255 & 12 & 4 \\
\hline BG4 & 517 & 268 & 77 & 8 & 3 \\
\hline BG5 & 28152 & 14033 & 1000 & 15 & 3 \\
\hline BG6 & 16723 & 8484 & 740 & 17 & 4 \\
\hline BG7 & 30166 & 15403 & 974 & 15 & 4 \\
\hline BG8 & 30928 & 15706 & 1028 & 15 & 3 \\
\hline BG9 & 8382 & 4489 & 446 & 13 & 4 \\
\hline BG10 & 10714 & 5526 & 13 & 4 \\
\hline
\end{tabular}




\section{Table 6(on next page)}

List of the lowest taxonomic food items in the diet of geese.

GWFG = Greater white-fronted goose; $B G=$ Bean goose. $F_{s}$, percentage of sequences in DNA metabarcoding; $F_{m}$, percentage of epidermis squares in microhistological analysis. 


\begin{tabular}{|l|c|c|c|c|c|c|c|}
\hline \multirow{2}{*}{ Food items } & \multirow{2}{*}{$\begin{array}{c}\text { Level of } \\
\text { identification }\end{array}$} & \multicolumn{3}{|c|}{ GWFG } & \multicolumn{4}{c|}{ BG } \\
\cline { 5 - 9 } & N reads & $\mathrm{F}_{\mathrm{s}}(\%)$ & $\mathrm{F}_{\mathrm{m}}(\%)$ & $\mathrm{N}$ reads & $\mathrm{F}_{\mathrm{s}}(\%)$ & $\mathrm{F}_{\mathrm{m}}(\%)$ \\
\hline Poaceae spp. (except Poa annua) & Family & 51705 & 47.98 & 45.68 & 0 & 0.00 & 0.00 \\
\hline Poa annua & Species & 23554 & 21.86 & 0.00 & 167 & 0.20 & 0.00 \\
\hline Carex heterolepis & Species & 18867 & 17.51 & 16.39 & 81457 & 99.49 & 62.85 \\
\hline Carex spp. (except Carex heterolepis) & Genus & 9706 & 9.01 & 2.31 & 191 & 0.23 & 3.49 \\
\hline Alopecurus aequalis & Species & 3458 & 3.21 & 0.00 & 0 & 0.00 & 0.00 \\
\hline Potentilla chinensis & Species & 184 & 0.17 & 1.18 & 65 & 0.08 & 2.06 \\
\hline Cynodon dactylon & Species & 155 & 0.14 & 0.00 & 0 & 0.00 & 0.00 \\
\hline Polygonum spp. & Genus & 56 & 0.05 & 0.00 & 0 & 0.00 & 0.00 \\
\hline Stellaria media & Species & 26 & 0.02 & 0.00 & 0 & 0.00 & 0.00 \\
\hline Ranunculus chinensis & Species & 14 & 0.02 & 0.00 & 0 & 0.00 & 0.00 \\
\hline Lapsana apogonoides & Species & 11 & 0.02 & 0.00 & 0 & 0.00 & 0.00 \\
\hline Asteraceae sp. & Genus & 16 & 0.01 & 2.33 & 0 & 0.00 & 14.55 \\
\hline Alopecurus & Genus & 0 & 0.00 & 30.93 & 0 & 0.00 & 13.18 \\
\hline Carex thunbergii & Species & 0 & 0.00 & 0.54 & 0 & 0.00 & 2.79 \\
\hline Fabaceae sp. & Genus & 0 & 0.00 & 0.64 & 0 & 0.00 & 1.08 \\
\hline
\end{tabular}




\section{Figure 1}

Technical flowchart of this study.
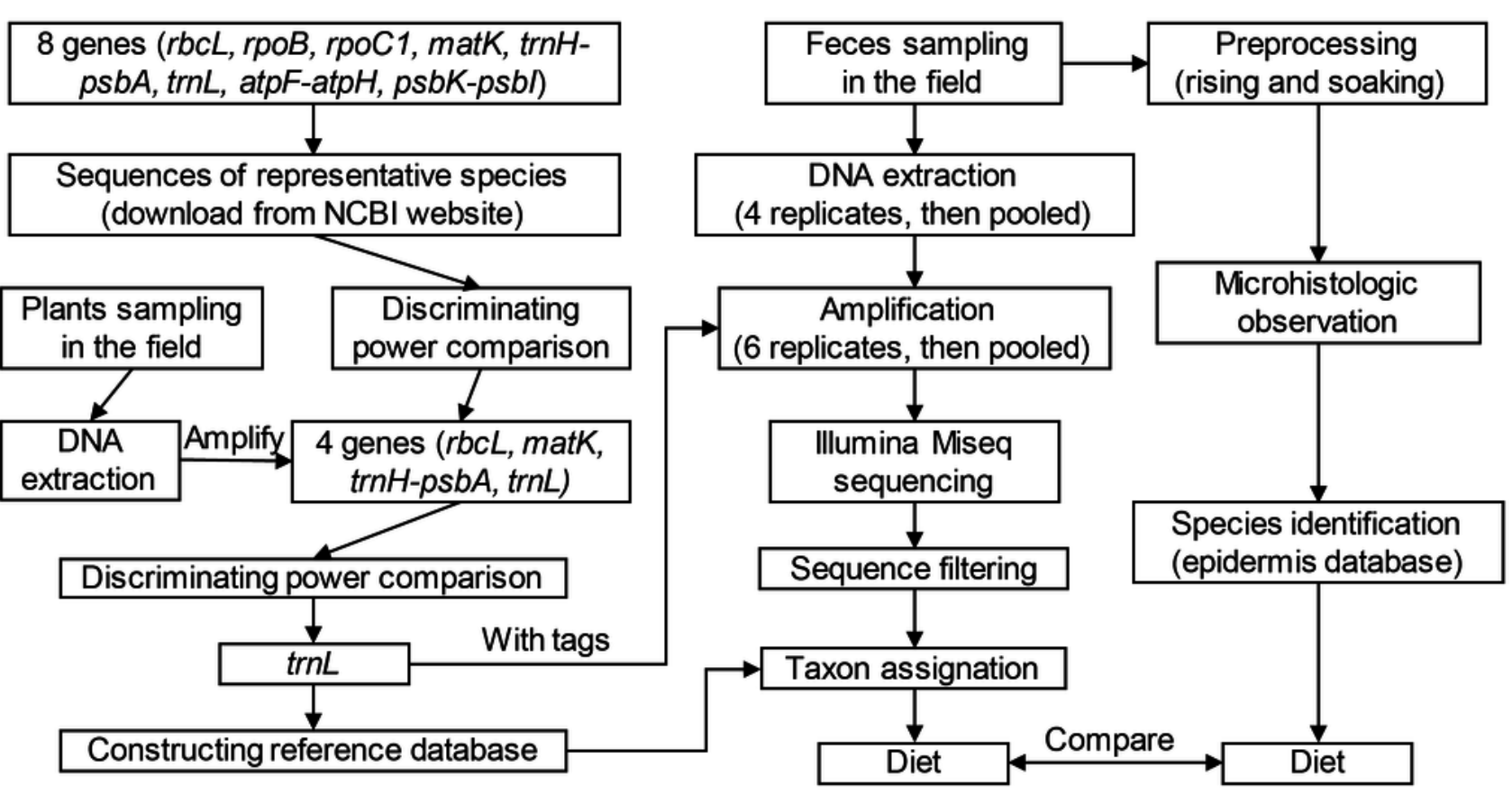
Figure 2

The location of our study area, Shengjin Lake National Nature Reserve and our sampling sites. (Source: http://eros.usgs.gov/\# ).

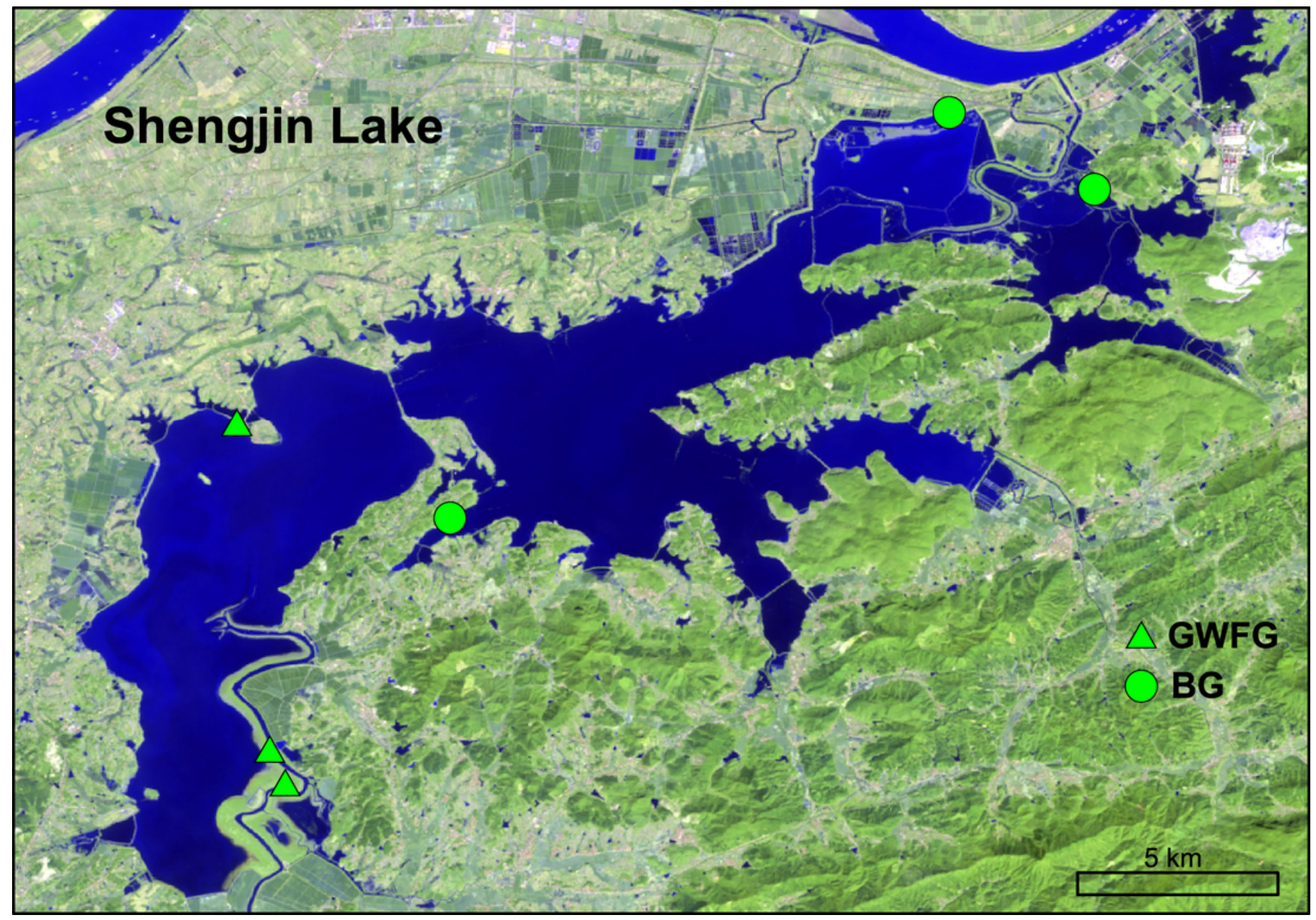

